Article

\title{
Ammonia Emissions in SI Engines Fueled with LPG
}

\author{
Andrzej Żółtowski * and Wojciech Gis
}

Motor Transport Institute, 80 Jagiellonska Str., 03-301 Warsaw, Poland; wojciech.gis@its.waw.pl

* Correspondence: andrzej.zoltowski@its.waw.pl

check for

updates

Citation: Żółtowski, A.; Gis, W. Ammonia Emissions in SI Engines Fueled with LPG. Energies 2021, 14, 691. https://doi.org/10.3390/en 14030691

Academic Editors: Dimitrios

C. Rakopoulos and Jacek Pielecha

Received: 24 November 2020

Accepted: 21 January 2021

Published: 29 January 2021

Publisher's Note: MDPI stays neutral with regard to jurisdictional claims in published maps and institutional affiliations.

Copyright: (C) 2021 by the authors. Licensee MDPI, Basel, Switzerland. This article is an open access article distributed under the terms and conditions of the Creative Commons Attribution (CC BY) license (https:// creativecommons.org/licenses/by/ $4.0 /)$.

\begin{abstract}
Ammonia is a toxic exhaust component emitted from internal combustion engines. Both pure ammonia and the products of its reaction with nitrogen and sulfur compounds, being the source of particulate matter (PM) emissions, are dangerous for human health and life. The aim of the article was to demonstrate that $\mathrm{NH}_{3}$ can be produced in exhaust gas after-treatment systems of spark-ignition (SI) engines used in light-duty vehicles. In some cases, $\mathrm{NH}_{3}$ occurs in high enough concentrations that can be harmful and dangerous. It would be reasonable to collect research data regarding this problem and consider the advisability of limiting these pollutant emissions in future regulations. The article presents the results of the spark-ignition engine testing on an engine test bench and discusses the impact of the air-fuel ratio regulation and some engine operating parameters on the concentration of $\mathrm{NH}_{3}$. It has been proven that in certain engine operating conditions and a combination of circumstances like the three-way catalytic reactor (TWC) temperature and periodic enrichment of the air-fuel mixture may lead to excessive $\mathrm{NH}_{3}$ emissions resulting from the $\mathrm{NO}$ conversion in the catalytic reactor. This is a clear disadvantage due to the lack of limitation of these pollutant emissions by the relevant type-approval regulations. This article should be a contribution to discussion among emissions researchers whether future emission regulations (e.g., Euro 7 or Euro VII) should include a provision to reduce $\mathrm{NH}_{3}$ emissions from all vehicles.
\end{abstract}

Keywords: SI engines; pollutant emissions; ammonia; emissions regulations

\section{Introduction}

Ammonia is a toxic substance classified by international regulations [1]. US regulations allow for the $\mathrm{NH}_{3}$ concentration limit of $25 \mathrm{ppm}$ during 8-h human exposure [2]. $\mathrm{NH}_{3}$ is not a product forming itself inside the engine combustion chamber during the combustion process. In spark ignition (SI) engines, $\mathrm{NH}_{3}$ is formed in exhaust after-treatment systems during $\mathrm{NO}$ conversion in the presence of $\mathrm{CO}$. Moreover, $\mathrm{NH}_{3}$ may react with the acids contained in the exhaust gas, forming particulate matter (PM) and harmful aerosols. Exposure to higher $\mathrm{NH}_{3}$ concentration could cause irritation of the skin, eyes, nose, or throat due to direct contact. Ammonia, even at low concentrations, has an unpleasant odor when released into the air but most notably harms vegetation, particularly at high concentrations. In water bodies, ammonia causes more serious harm due to the toxicity to organisms living in water [3]. Regulation No. 595/2009 for the value of $\mathrm{NH}_{3}$ concentration in Euro VI has set 10 ppm as the limit for $\mathrm{NH}_{3}$ concentration in the exhaust gas emitted from a heavy-duty vehicle [4]. So far, there are no $\mathrm{NH}_{3}$ limits for light-duty vehicles.

$\mathrm{NH}_{3}$ emissions have been associated mainly with the emissions from heavy-duty vehicles using selective catalytic reduction (SCR) as an after-treatment device. This type of catalytic reactor allows us to reduce $\mathrm{NO}_{\mathrm{x}}$ emissions in the exhaust of the engines fueled with a lean air-fuel mixture. In a stoichiometric engine, carbon monoxide is used to reduce nitrogen oxides inside three-way catalytic reactors (TWCs). In compression ignition engines, fueled with a lean air-fuel mixture with an excess of oxygen, most of the $\mathrm{CO}$ contained in the exhaust gases is oxidized to $\mathrm{CO}_{2}$. This process slows down the $\mathrm{NO}_{\mathrm{x}}$ conversion and prevents the use of such reactors in stoichiometric spark-ignition engines. The operation principle of SCR reactors is based on the use of chemical reactions between 
nitrogen oxides and ammonia formed from urea injected into the reactor [4]. Overdosing of the amount of injected urea results in increased $\mathrm{NH}_{3}$ emissions from the exhaust system. However, urea overdosing is not the only factor increasing $\mathrm{NH}_{3}$ emissions from the internal combustion engine. $\mathrm{NH}_{3}$ can also be emitted from a spark ignition engine operating as a stoichiometric engine. $\mathrm{NH}_{3}$ emissions are mainly produced from $\mathrm{NO}$ emissions by reactions (1) and (2).

$$
\begin{gathered}
2 \mathrm{NO}+4 \mathrm{CO}+2 \mathrm{H}_{2} \mathrm{O}+\mathrm{H}_{2} \rightarrow 2 \mathrm{NH}_{3}+4 \mathrm{CO}_{2} \\
2 \mathrm{NO}+5 \mathrm{H}_{2} \rightarrow 2 \mathrm{NH}_{3}+2 \mathrm{H}_{2} \mathrm{O}
\end{gathered}
$$

The greater the concentrations of $\mathrm{NO}, \mathrm{CO}$, and $\mathrm{H}_{2}$ in the exhaust gas are, the greater the mass of the $\mathrm{NH}_{3}$ is. These gases are the basic components of the exhaust gas on which the mass of the $\mathrm{NH}_{3}$ depends. $\mathrm{CO}$ is a natural component of exhaust gases and has higher concentrations when the air-fuel mixture is rich. $\mathrm{H}_{2}$ can be obtained in the exhaust gas in two ways-during the combustion stroke, where, under high pressures and temperature, the hydrogen contained in the fuel is released or by means one of the below reactions: the water gas shift (3) or the steam reforming (4).

$$
\begin{gathered}
\mathrm{CO}+\mathrm{H}_{2} \mathrm{O} \rightarrow \mathrm{CO}_{2}+\mathrm{H}_{2} \\
\mathrm{C}_{\mathrm{n}} \mathrm{H}_{\mathrm{m}}+\mathrm{n} \mathrm{H} \mathrm{H}_{2} \mathrm{O} \rightarrow \mathrm{n} \mathrm{CO}+(\mathrm{m} / 2+\mathrm{n}) \mathrm{H}_{2}
\end{gathered}
$$

Thus, higher engine $\mathrm{NO}, \mathrm{CO}, \mathrm{HC}$, and $\mathrm{H}_{2}$ emissions could bring about higher $\mathrm{NH}_{3}$ emissions. It can be seen that the type of used fuel may have an influence on the amount of $\mathrm{H}_{2}$ produced in the combustion chamber according to reaction (4). In particular, the value of $\mathrm{n} / \mathrm{m}$ fuel ratio is important. For lighter gaseous fuels, such as methane or propane, a higher value of the $\mathrm{n} / \mathrm{m}$ ratio means that the fuel contains more hydrogen, and therefore more water will be formed in the products of its combustion, which, according to reactions (3) and (4), may change the quantity of hydrogen participating in the process of $\mathrm{NH}_{3}$ formation. In a stoichiometric engine, lambda sensor periodically and alternately changes the air-fuel ratio between rich-to-lean stages, but the average air-fuel equivalent ratio oscillates around a value equal to 1.00. During engine operation, it is possible to identify the operating conditions in which the engine has a rich $(\lambda<1.00)$ and a lean $(\lambda>1.00)$ air-fuel ratio. When the air-fuel mixture is rich, conditions for the formation of $\mathrm{NH}_{3}$ occur. Due to the limited access to oxygen, the raw exhaust gas will contain more $\mathrm{CO}$ and unburned hydrocarbons $\left(\mathrm{C}_{\mathrm{n}} \mathrm{H}_{\mathrm{m}}\right)$, because these gases cannot be fully oxidized. This situation leads to the generation of $\mathrm{NH}_{3}$ emissions in accordance with reactions (1)-(4).

The greater and deeper the changes of the air-fuel ratio occur, the greater tendency the engine shows for increasing $\mathrm{NH}_{3}$ emissions. Therefore, by analyzing the influence of air-fuel ratio on $\mathrm{NH}_{3}$ emissions, it can be assumed that the engine will have the lowest $\mathrm{NH}_{3}$ emission during operation in stationary, steady-state conditions with constant speed and torque. In the event of a sudden change of operating parameters, e.g., rapid acceleration of the vehicle during aggressive driving and temporary enrichment of air-fuel ratio, or only with frequent changes of the engine operating parameters caused by the vehicle's driving, conditions for higher $\mathrm{NH}_{3}$ emissions will be created.

Apart from the concentration of gases participating in the reactions (1) and (2) (NO, $\mathrm{CO}$, and $\mathrm{H}_{2}$ ), the mass of $\mathrm{NH}_{3}$ emission will be determined by the kinetics of these reactions depending on the temperature at which the $\mathrm{NO}$ converts to $\mathrm{NH}_{3}$. According to [5], reaction (3) takes place at lower TWC temperatures $\left(300-500{ }^{\circ} \mathrm{C}\right)$, whereas reaction (4) occurs at higher temperatures $\left(>500{ }^{\circ} \mathrm{C}\right)$.

Gaseous ammonia has been shown to contribute to the formation of airborne particulate matter. Ammonia emitted into ambient air neutralizes nitric and sulfuric acid to form ammonia nitrate $\left(\mathrm{NH}_{4} \mathrm{NO}_{3}\right)$ and sulfate $\left(\mathrm{NH}_{4}\right)_{2} \mathrm{SO}_{4}$, two important components contributing to airborne fine particles or PM2.5. As has been stated by International Agency for Research on Cancer, a part of the World Health Organization (WHO), particulate matter 
is a major constituent of outdoor air pollution and can cause cancer in humans (IARC 2013). In addition to human health effects, ammonia also impacts terrestrial vegetation.

Three-way catalysts have been used in modern light-duty vehicles driven by sparkignition engines for over three decades since the introduction of low-emission vehicles to the automotive market. Today, this is a typical part of the exhaust after-treatment system. The time that has elapsed since the start of using SCR technology in heavy-duty vehicles is a little shorter. TWC and SCR are identified as the main causes of $\mathrm{NH}_{3}$ emissions in the exhaust gas. Although agriculture is still the main source of $\mathrm{NH}_{3}$ emissions to the atmosphere, some researchers have reported an increase in $\mathrm{NH}_{3}$ emissions from vehicles in recent years.

Ammonia emitted into the ambient air has the ability to react with nitric acid to form solid ammonium nitrate, which is the secondary source of pollutant emissions in the form of $\mathrm{PM}$ emissions. For this reason, an increase in $\mathrm{NH}_{3}$ emissions to the atmosphere can be dangerous and undesirable. Therefore, it is time to take a closer look at the problem of $\mathrm{NH}_{3}$ emissions from vehicles, including also those powered by SI engines.

The literature on the formation and modeling of ammonia emissions in SI engines is quite extensive. Descriptions of these issues can be found in [6-25]. However, there is still a lack of knowledge of the influence of the TWC processes on the NH3 emissions in the emission test cycles.

\section{Results of the Testing}

\subsection{Test Bed and Tested Object}

The aim of the testing was to determine the influence of selected engine parameters on $\mathrm{NH}_{3}$ emissions. The experimental testing was carried out on a spark-ignition engine fueled with propane. It was a V-type engine with a displacement of $7.2 \mathrm{dm}^{3}$, equipped with two TWCs. The diameter of the TWC's metal substrate was $148 \mathrm{~mm}$, catalyst body volume $4.22 \mathrm{dm}^{3}$, cell density $400 \mathrm{cpsi}$, and precious metal charge $70 \mathrm{~g} / \mathrm{ft}^{3}$ with $\mathrm{Pt} / \mathrm{Pd} / \mathrm{Rh}$ ratio of 1:5:4. The engine was tested on the test bench equipped with measurement equipment complying with requirements of UN Regulation No. 49.06 and EU Regulation No. 582/2011.

The tests were performed on the test bench equipped with the following devices:

- engine dynamometer as an asynchronous electric machine (capable of operating in the motor-generator mode) by AVL type AFA 100 4Z4/4;

- $\quad$ system for particulate sampling Smart Sampler AVL 472 by AVL;

- particle counter AVL489 APC ADVANCED by AVL enabling measurement of particulate number concentration in raw sampling;

- a set of AMA i60 by AVL exhaust gases analyzers for analyzing the raw exhaust gas, consisting of

- type AVL IRD i60 $\mathrm{CO}_{2} / \mathrm{COL}$ analyzer by $\mathrm{ABB}$ operating on the principle of infrared absorption (NDIR);

- type AVL IRD i60 $\mathrm{CO}_{2} / \mathrm{COH}$ analyzer by $\mathrm{ABB}$ adapted for measuring $\mathrm{CO}_{2}$ and high $\mathrm{CO}$ concentrations, operating on the bases of the absorption of infrared radiation (NDIR) measuring the concentration of gas in the dry exhaust gases;

- a heated analyzer of the total hydrocarbons (THC) AVL Cutter FID i60 HDD type by AVL, operating on a principle of flame ionization detection (FID). The analyzer was equipped with a non-methane hydrocarbons separator (cutter), which enabled the analyzer to measure concentrations of $\mathrm{THC}$ and $\mathrm{CH}_{4}$;

- a heated analyzer $\mathrm{NO} / \mathrm{NO}_{\mathrm{x}}$ of AVL CLD i60 HDD type operating on a principle of chemiluminescence;

- a set of calibration gases with accuracy $1 \%$ used for calibration of the analyzers;

- AVL AMA i60 LDD NH $\mathrm{N}_{3} / \mathrm{H}_{2} \mathrm{O}$ type analyzer by AVL being a diode laser gas analyzer with a measuring principle based on the specific light absorption of different gas components; 
- $\quad$ airflow meter Sensyflow P-type to measure the air consumption of by the engine, operating on the principle of measuring the resistance of the heated wire;

- mass flowmeter CMF 025M 300 NQFZGZZZ by Emerson for measurement of gaseous fuel consumption, operating on Coriolis principle.

The used experimental equipment allowed to ensure the accuracy of emission measurements of $2 \%$.

\subsection{Result of the Testing}

Figure 1 shows the $\mathrm{NH}_{3}$ concentration in the exhaust gas and the exhaust temperature during the hot World Harmonized Transient Cycle (WHTC). In accordance with UN Regulation No. 49.06, the WHTC cycle is a commonly used pollutant emissions test in Euro VI standard. The figure shows that $\mathrm{NH}_{3}$ reaches relatively low concentrations at both low and high exhaust gas temperatures, which roughly corresponds to the urban and highway phases of the WHTC cycle. The relatively high concentration of $\mathrm{NH}_{3}$ is achieved during rural driving, where the exhaust gas temperature is approx. $550-600{ }^{\circ} \mathrm{C}$.
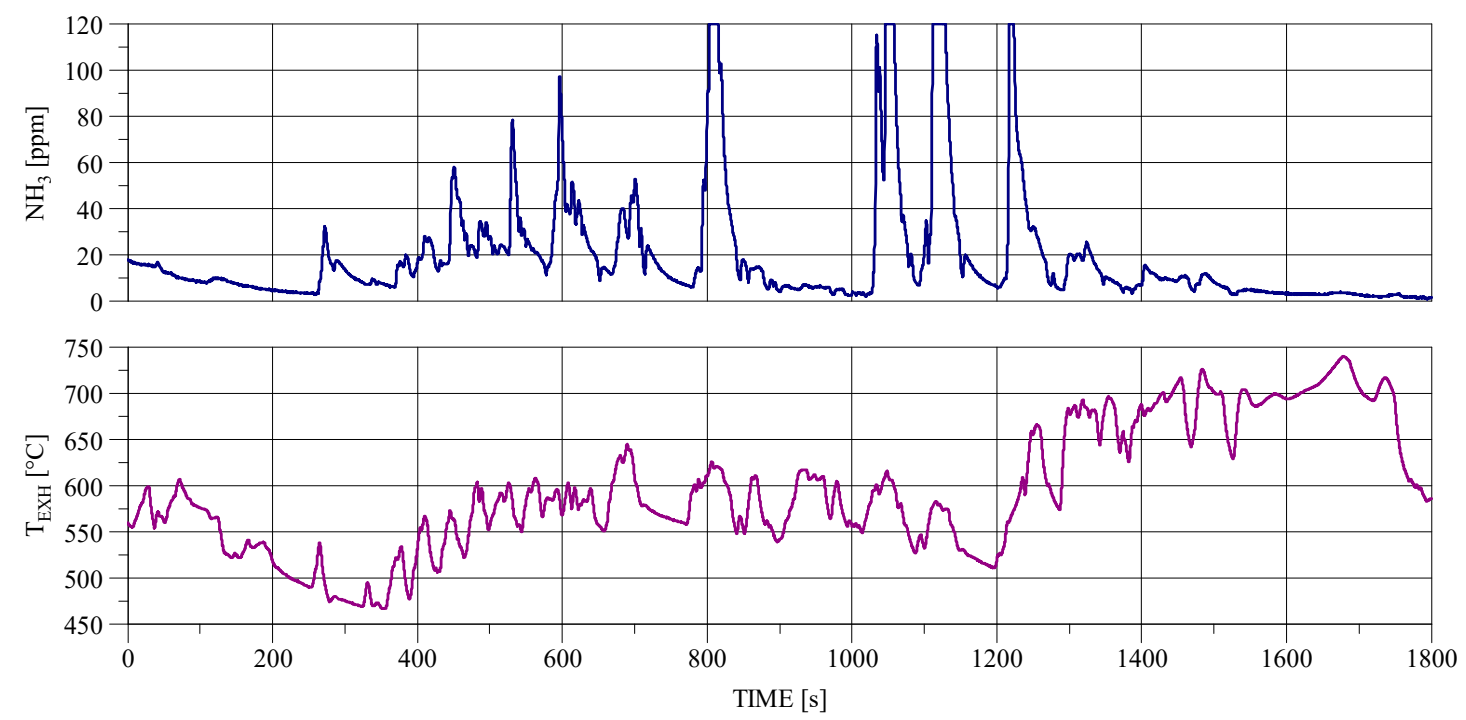

Figure 1. $\mathrm{NH}_{3}$ concentration and exhaust gas temperature in the hot World Harmonized Transient Cycle (WHTC).

Figure 2 shows the dependence of $\mathrm{NH}_{3}$ concentration and the exhaust gas temperature in the WHTC cycle. The total duration of the WHTC cycle is $1800 \mathrm{~s}$. The cycle covers three successive different types of driving conditions-urban, rural, and highway, $600 \mathrm{~s}$ each. Urban driving mode is characterized by the greatest frequency of changes in engine speed and loading. In highway driving mode, the changes of engine speed and loading are relatively the smallest.

The highest concentrations of $\mathrm{NH}_{3}$ correspond to the exhaust gas temperature range of 570-625 ${ }^{\circ} \mathrm{C}$. Outside this temperature range, the $\mathrm{NH}_{3}$ concentration decreases with both increasing and decreasing temperature. The distribution of $\mathrm{NH}_{3}$ concentrations (Figure 2) indicates that the $\mathrm{NH}_{3}$ concentration increases along with the increase in exhaust gas temperature from the lowest values to approx. $570{ }^{\circ} \mathrm{C}$. This means that one of the reactions responsible for the $\mathrm{NH}_{3}$ formation (i.e., (1) or (2)) is accelerated. It is claimed [3] that this is an effect of water gas shift reaction (reaction (3)). At higher temperatures, this reaction slows down and the hydrogen needed for $\mathrm{NH}_{3}$ formation is produced as a result of hydrocarbons steam reforming (reaction (4)). 


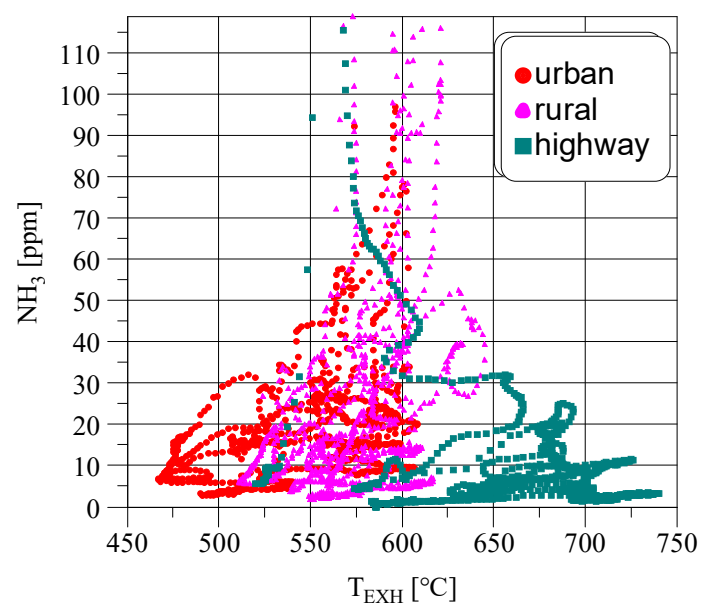

Figure 2. $\mathrm{NH}_{3}$ concentration versus exhaust gas temperature $\left(\mathrm{T}_{\mathrm{EXH}}\right)$ in the hot WHTC cycle.

Most of the registered points in the WHTC cycle having the highest concentrations of $\mathrm{NH}_{3}$ (Figure 2) correspond to the exhaust gas temperatures with the highest frequency of occurrence in the cycle (Figure 3); hence, they have significant importance and influence on total $\mathrm{NH}_{3}$ emissions in the whole emission cycle.

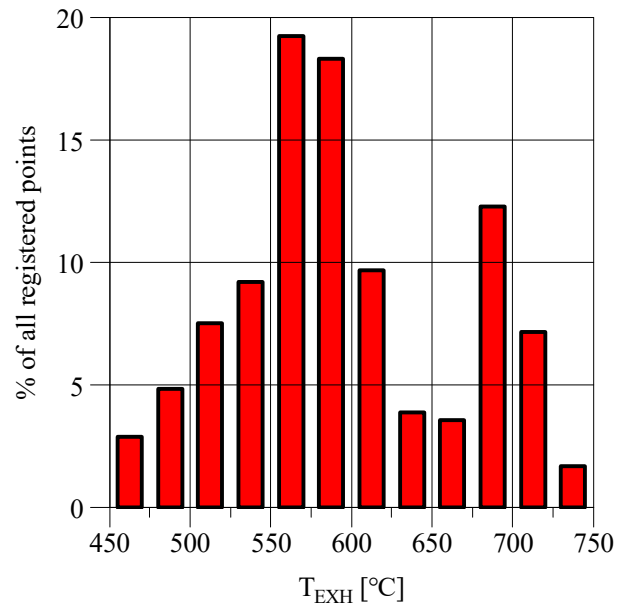

Figure 3. Histogram showing the relative frequency (in \%) of exhaust gas temperature in classes with a width of $25^{\circ} \mathrm{C}$.

The concentrations of the gases participating in the reactions (1)-(4) should be correlated with each other. However, only the concentration of $\mathrm{CH}_{4}$ from the concentrations of $\mathrm{NO}, \mathrm{CO}$, particulate number emissions (PN), and $\mathrm{CH}_{4}$ presented in Figure 4, i.e., all exhaust gas components related to the formation of $\mathrm{NH}_{3}$, is similar to the course of $\mathrm{NH}_{3}$ concentrations (Figure 2). This observation is confirmed by the values of the correlation coefficients presented in Table 1.

The correlation coefficient $(r)$ between $x$ and $y$ parameters were calculated in accordance with Formula (5). This is a measure of the relationship between two measured data values.

$$
r=\frac{\sum_{i=1}^{n}\left(x_{i}-\bar{x}\right)\left(y_{i}-\bar{y}\right)}{\sqrt{\sum_{i=1}^{n}\left(x_{i}-\bar{x}\right)^{2}} \sqrt{\sum_{i=1}^{n}\left(y_{i}-\bar{y}\right)^{2}}}
$$

where $x_{i}, y_{i}$ are the current values of $x$ and $y$ parameters as a function of time in the WHTC cycle, $\bar{x}, \bar{y}$ are the mean values of parameters $x$ and $y$ in the WHTC cycle, and $n=18,000$ is the number of registered points in the test. 

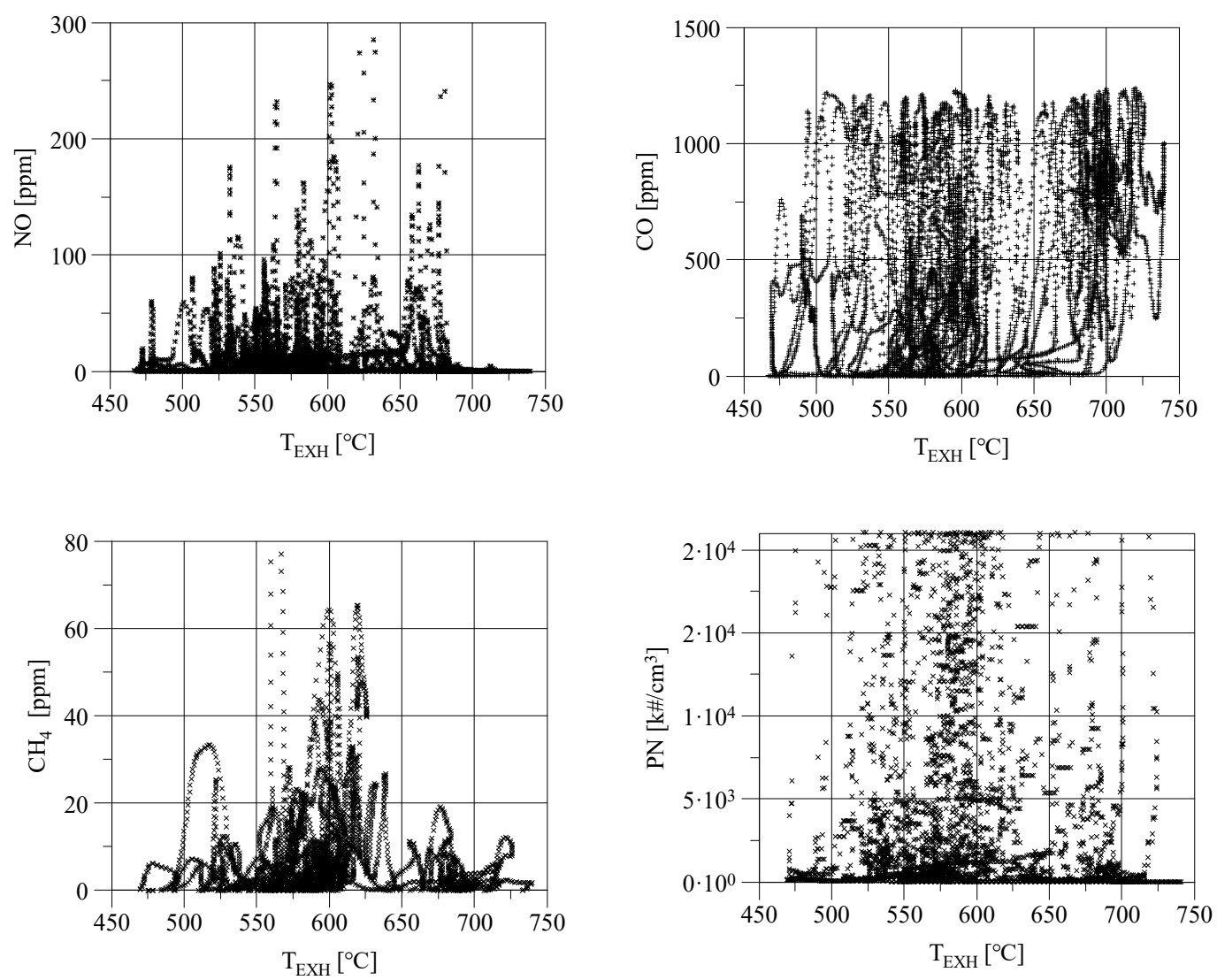

Figure 4. The concentration of different exhaust gas components at the three-way catalytic reactor (TWC) outlet in the hot WHTC cycle as a function of exhaust gas temperature.

Table 1. Correlation coefficients of $\mathrm{NH}_{3}$ concentration and selected exhaust component at the TWC outlet.

\begin{tabular}{cc}
\hline Exhaust Component & Correlation \\
\hline NO & 0.12 \\
CO & 0.06 \\
PN & 0.08 \\
CH4 (whole WHT cycle) & 0.63 \\
CH4 (urban) & 0.55 \\
CH4 (rural) & 0.62 \\
CH4 (highway) & 0.75 \\
\hline
\end{tabular}

Small values of the correlation coefficient for NO, CO, and PN (Table 1) indicate that used TWC had proper conversion efficiency for these pollutants, and its efficiency was independent of $\mathrm{NH}_{3}$ concentration. A much stronger correlation between $\mathrm{NH}_{3}$ and $\mathrm{CH}_{4}$ means that TWC had rather poor conversion efficiency for $\mathrm{CH}_{4}$, and as a result, a linear relationship can be found between concentrations of these two exhaust gas components.

In $\mathrm{SI}$ engines, $\mathrm{NO}$ and $\mathrm{CH}_{4}$ concentrations depend on engine loading, and for this reason, the initial increase of $\mathrm{NO}$ and $\mathrm{CH}_{4}$ concentrations in Figure 4 is due to the increase of the engine loading. It can be observed that the maximum of $\mathrm{NO}$ and $\mathrm{CH}_{4}$ concentrations occur at $\mathrm{T}_{\mathrm{EXH}}=600-625^{\circ} \mathrm{C}$ and then decrease with increasing exhaust gas temperature. This means that the TWC's conversion efficiency and the decrease of NO and $\mathrm{CH}_{4}$ concentrations caused by it become greater in this temperature than the increase of the concentration caused by the engine loading changes. TWC used in the tests has sufficient efficiency of $\mathrm{CO}$ and $\mathrm{NMHC}$ oxidation in the whole operating range of the exhaust gas temperature shown in Figure 4 . However, $\mathrm{CH}_{4}$ conversion efficiency apparently depends 
on the temperature. It may be an effect of the commonly known fact that methane oxidizes poorly in platinum-dominant catalytic converters used in gasoline-powered engines. The effect of exhaust gas temperature on the PN number concentration is difficult to notice.

The strong correlation between $\mathrm{NH}_{3}$ and $\mathrm{CH}_{4}$, especially for $\mathrm{CH}_{4}$ emitted in the highway phase of the emission cycle, confirms an important role that reaction (4) plays in the creation of conditions for the $\mathrm{NH}_{3}$ formation. In particular, it means that when the exhaust gas temperature increases (transition from the urban phase to the highway phase), the share of reaction (4) in the $\mathrm{NH}_{4}$ formation process increases, which proves that the share of reaction (3) in this process is simultaneously decreasing.

Figure 5 shows the relative rate of mass emissions $\left(\mathrm{NO}, \mathrm{CH}_{4}, \mathrm{CO}\right.$, and $\left.\mathrm{NH}_{3}\right)$ and particulate number emissions (PN) in the WHTC cycle. In this figure, it can be seen that each pollutant is emitted with different mass rates expressed as a percentage of the total mass emissions of a pollutant. In the initial phase of the test (urban driving), the relative rate of emission is approximately constant for each pollutant. This part of the WHTC cycle is characterized by relatively low exhaust gas temperatures, relatively low average engine load, and frequent changes in engine loading and speed. In the rural phase of the WHTC cycle (600-1200 s), where the exhaust gas temperature, engine loading, and its speed increase, and the frequency of gear changes and braking decreases, the TWC reactor operates with greater efficiency, which significantly reduces the mass rate of $\mathrm{CO}$ emissions. At the same time, $\mathrm{CH}_{4}$ emissions increase as a result of the poor efficiency of catalytic converter for $\mathrm{CH}_{4}$ conversion and more exhaust mass flow through the exhaust system.

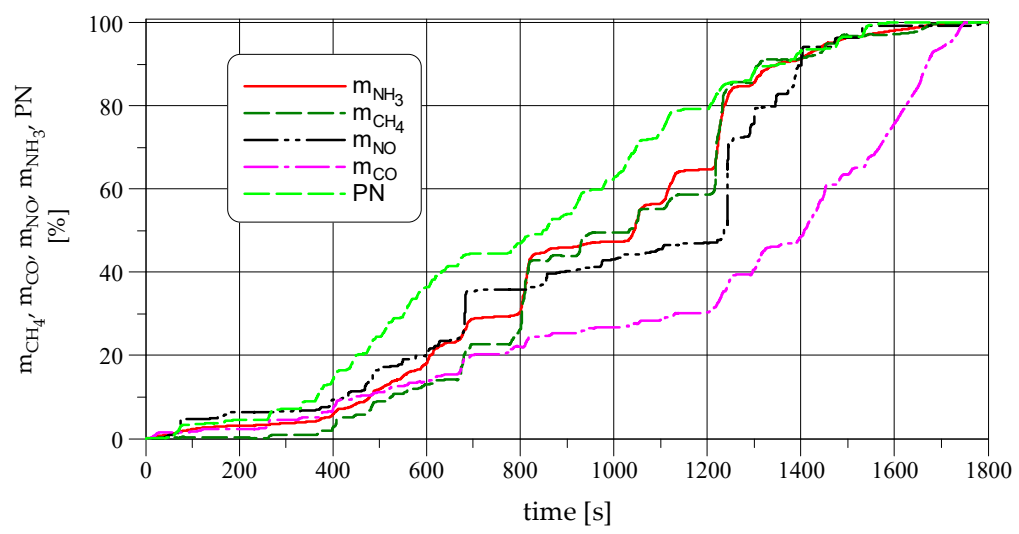

Figure 5. The relative rate of mass emissions in the WHTC cycle.

Throughout the WHTC cycle, the mass rate of $\mathrm{CH}_{4}$ and $\mathrm{NH}_{3}$ emissions are similar to each other. In the rural phase of the WHTC cycle, the rate of particle number (PN) emissions has increased compared to other pollutants. This may be the result of a higher concentration of $\mathrm{NH}_{3}$ in this part of the test cycle and, as a result, acceleration of the reactions (6) and (7), whose product is particulate matter. Comparing the relative mass emission of different pollutants in the rural fragment of the WHTC cycle, it can be observed that the relative mass rate of $\mathrm{NH}_{3}$ increases faster than the $\mathrm{NO}$ and $\mathrm{CO}$ emissions. Reactions (1)-(3) in which $\mathrm{CO}$ and $\mathrm{NO}$ are involved directly or indirectly may be responsible for this phenomenon.

In the final phase of the WHTC cycle (highway driving), the exhaust gas temperature increases to its maximum value. It reduces the $\mathrm{NH}_{3}$ concentration as an effect of more stable driving. This results in the decrease of the $\mathrm{NH}_{3}$ emission rate in the final part of the WHTC cycle, and the equalization of the rate of $\mathrm{NH}_{3}, \mathrm{CH}_{4}$, and $\mathrm{PN}$ of emissions changes as a consequence.

Table 2 shows the masses of emitted pollutants and their specific emissions. Based on the stoichiometry of reactions (1) and (2), it can be determined that $0.56 \mathrm{~kg}$ of $\mathrm{NH}_{3}$ was produced from $1 \mathrm{~kg}$ of $\mathrm{NO}$, which means that $1.41 \mathrm{~g}$ of $\mathrm{NO}$ was used to produce $0.79 \mathrm{~g}$ of $\mathrm{NH}_{3}$ stated in Table 2. Similarly, it can be determined that an additional $3.9 \mathrm{~g}$ of $\mathrm{CO}$ was consumed in reaction (1) to make $0.79 \mathrm{~g}$ of $\mathrm{NH}_{3}$. The above stoichiometric 
calculations show that if the engine did not generate $\mathrm{NH}_{3}, \mathrm{NO}$ and $\mathrm{CO}$ emissions would have to increase by 360 and $19 \%$, respectively.

Table 2. Mass of pollutant and specific emissions in the tested engine in the WHTC cycle.

\begin{tabular}{ccc}
\hline Pollutant & $\begin{array}{c}\text { Mass of Pollutant } \\
{[\mathrm{g}]}\end{array}$ & $\begin{array}{c}\text { Specific Emissions } \\
{[\mathbf{m g} / \mathbf{k W h}]}\end{array}$ \\
\hline CO & 30.6 & 2045 \\
NOx & 0.81 & 54 \\
NO & 0.53 & 35 \\
THC & 0.24 & 16 \\
CH4 & 0.17 & 11 \\
NH3 & 0.79 & 53 \\
\hline
\end{tabular}

Figures 6 and 7 show cumulative masses of emissions and their ratios in the WHTC cycle determined by dividing the mass of $\mathrm{NH}_{3}$ emissions by the mass of the selected pollutants. This figure shows how the $\mathrm{NH}_{3}$ emission is changing in relation to other pollutants during the WHTC cycle. In contrast to the $\mathrm{NH}_{3} / \mathrm{THC}$ emission ratio, which is constant for most of the test, the $\mathrm{NH}_{3} / \mathrm{CO}$ and $\mathrm{NH}_{3} / \mathrm{NO}$ ratios have their visible maxima near the beginning of the highway driving, which is caused by the rapid increase of engine loading after idling.

The conditions for the formation of $\mathrm{NH}_{3}$ emissions occur when $\mathrm{NO}$ and $\mathrm{CO}$ are present in the exhaust gas. The concentrations shown in Figure 8 were measured at the TWC outlet of single cylinder row and are not real concentrations of $\mathrm{CO}$ and $\mathrm{NO}$ in raw exhaust at the inlet to the catalytic converter. In TWC, a significant part of the CO is oxidized and only a part of the $\mathrm{CO}$ is involved in the conversion of $\mathrm{NO}$ according to the following reactions:

$$
\begin{aligned}
& 2 \mathrm{NO}+\mathrm{CO} \rightarrow \mathrm{N}_{2} \mathrm{O}+\mathrm{CO}_{2} \\
& 2 \mathrm{NO}+\mathrm{H}_{2} \rightarrow \mathrm{N}_{2} \mathrm{O}+\mathrm{H}_{2} \mathrm{O}
\end{aligned}
$$

If no $\mathrm{NH}_{3}$ was formed in the TWC, the emissions of $\mathrm{NO}, \mathrm{NO}_{x}$, and $\mathrm{CO}$ (Table 2) could be greater. It is possible to trace (Figure 8) the coincidence of $\mathrm{CO}$ and $\mathrm{NO}$ concentration peaks with $\mathrm{NH}_{3}$ peaks. As already mentioned, in positive ignition engines, the $\mathrm{NH}_{3}$ emission depends on the $\mathrm{CO}$ emission, which in turn depends on the air-fuel ratio. In a stoichiometric engine equipped with a lambda sensor, the air-fuel ratio oscillates around 1.00 (Figure 9). The frequency and amplitude of these oscillations depend on the characteristics of the fuel control unit. If the changes of the air-fuel ratio take place in a narrower range than shown in Figure 9, lower $\mathrm{NH}_{3}$ emissions can be expected.

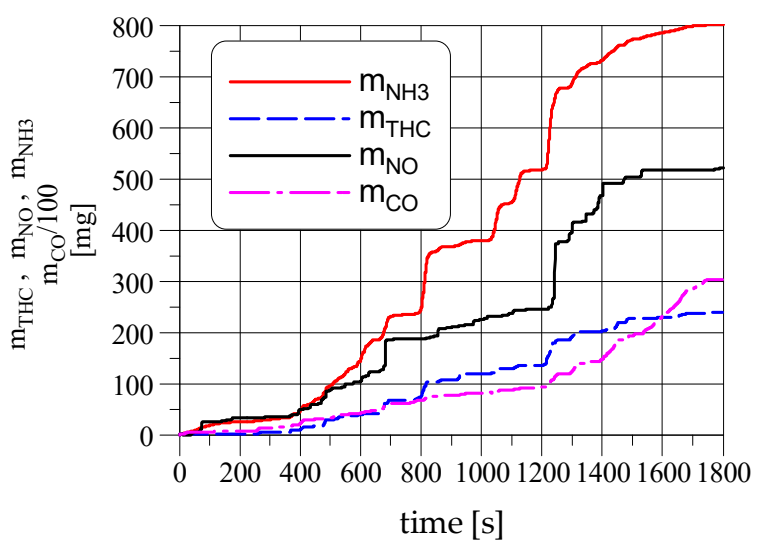

Figure 6. The cumulative mass of emissions versus time in the WHTC cycle. 


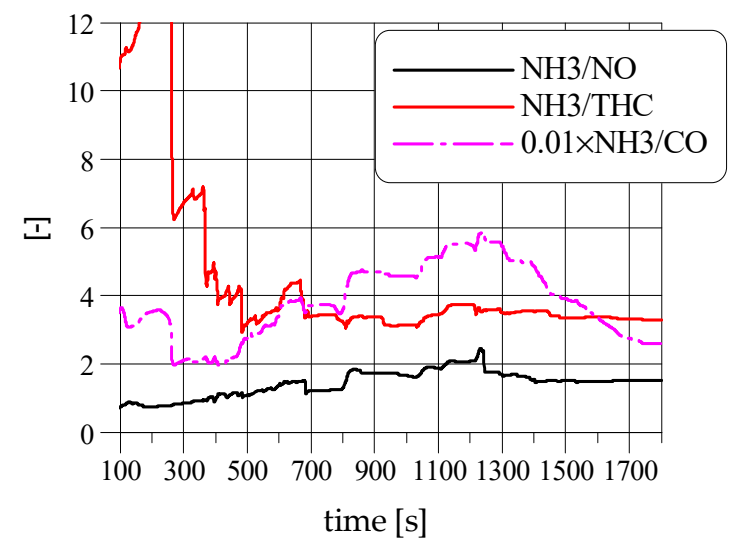

Figure 7. The cumulative mass of emissions ratios in the WHTC cycle.

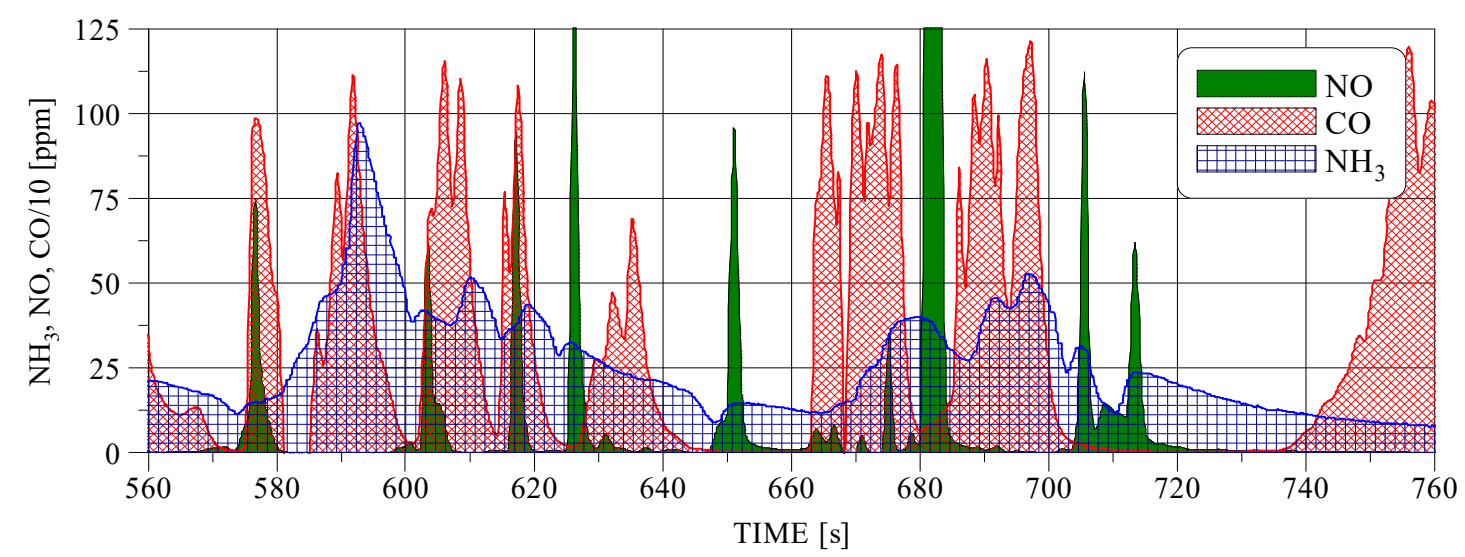

Figure 8. $\mathrm{CO}, \mathrm{NO}$, and $\mathrm{NH} 3$ concentrations at the outlet of the engine exhaust system in a fragment of the WHTC cycle.

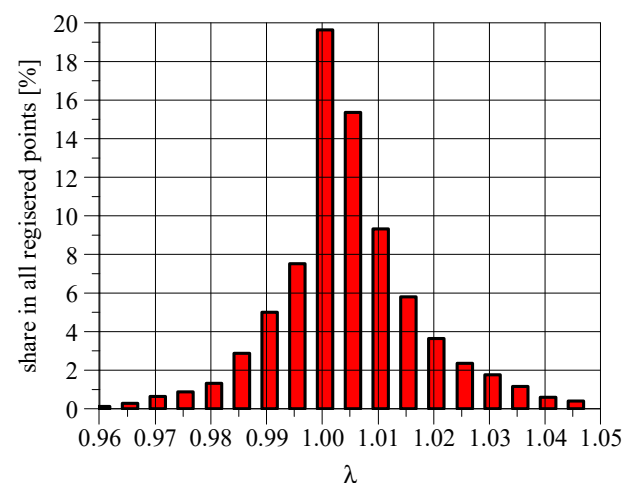

Figure 9. Histogram of relative air-fuel ratio distribution in classes with a width of 0.005 . Hot WHTC cycle.

Figure 10 shows that, as a result of various changes in the regulation of the engine control system and the exhaust after-treatment system, a significant change in the concentration of $\mathrm{NH}_{3}$ in the exhaust gas was achieved. As predicted, during greater $\mathrm{CO}$ emissions, more $\mathrm{NH}_{3}$ is formed due to the increased concentration of free $\mathrm{H}_{2}$ in the exhaust gas. When $\mathrm{NH}_{3}$ concentration is lower, $\mathrm{NO}$ emissions increase due to ceasing $\mathrm{NO}$ conversion to $\mathrm{NH}_{3}$.

Emissions of particulate mass (PM) and particulate number (PN) decrease with the increase in $\mathrm{NH}_{3}$ concentration, which may be partly due to the effect of converting ammonia to solid particles by the reaction of $\mathrm{NH}_{3}$ with nitric and sulfuric acids. Figure 10 shows that the desire to reduce $\mathrm{NH}_{3}$ emissions may result in an increase in particulate emissions. In 
the tested engine, it was necessary to use a particulate filter (DPF) as a part of the exhaust after-treatment system.
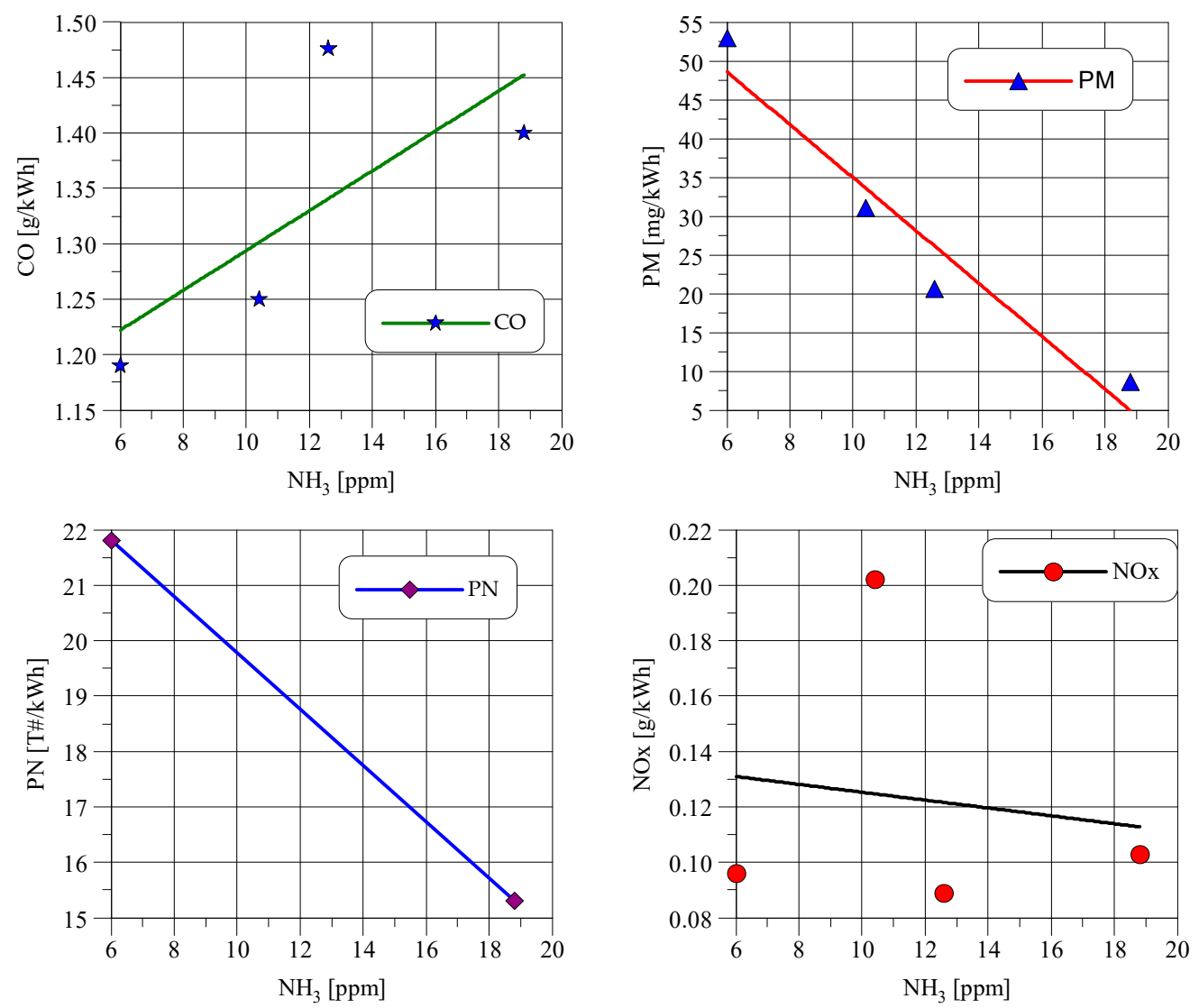

Figure 10. Emissions in the WHTC cycle versus mean $\mathrm{NH}_{3}$ concentration in the test.

\section{Discussion}

The conducted tests showed the ability to emit $\mathrm{NH}_{3}$ by SI engines. The combination of selected factors like TWC temperature, air-fuel ratio, or the type of precious metal coating in the TWC may cause an increase in $\mathrm{NH}_{3}$ emissions. The tested engine met the Euro VI requirements for all limited exhaust gas components (CO, NOx, NMHC, PM, and $\mathrm{PN}$ ) in each tested variant, but its $\mathrm{NH}_{3}$ emission was clearly dependent on the air-fuel regulation and the TWC used. If an engine taken from the tested engine family was used in a light-duty vehicle, it could still be characterized by excessive $\mathrm{NH}_{3}$ emissions despite passing the type-approval process. The influence of ammonia formation in the TWC on the emissions of particulate matter resulting from its reaction with nitric and sulfuric acids is not sufficiently investigated. It would be interesting to find an answer to the question of how much the fight against $\mathrm{NH}_{3}$ emissions would reduce the $\mathrm{PM}$ emissions at the same time.

$\mathrm{NH}_{3}$ is a toxic pollutant, the concentration of which in the atmosphere has been systematically increasing for many years [26]. This is mainly the effect of processes taking place in agriculture, but emissions from vehicles also participate in the increasing pollution. In vehicles' engines, the source of $\mathrm{NH}_{3}$ emissions can be ammonia slip in the diesel's SCR and the processes taking place in the three-way catalyst in SI engines. The article shows that the main way to reduce $\mathrm{NH}_{3}$ emissions in the $\mathrm{SI}$ engines is to reduce $\mathrm{CO}$ and $\mathrm{NO}$ emissions in the exhaust gas. In particular, this may be a significant problem in gaseous engines. Due to the greater value of hydrogen/carbon ratio in fuels such as CNG or LPG as compared to gasoline, exhaust gases from engines powered by gaseous fuels are characterized by a lower $\mathrm{CO}$ concentration and a higher content of $\mathrm{H}_{2} \mathrm{O}$. Based on reactions (2)-(4), a greater 
share of $\mathrm{H}_{2}$ in fuel and $\mathrm{H}_{2} \mathrm{O}$ in the exhaust gas can be considered stimulating factors in $\mathrm{NH}_{3}$ emissions. As it is commonly known, the TWC technology uses $\mathrm{CO}$ for $\mathrm{NO}$ conversion. To ensure $\mathrm{CO}$ required mass for $\mathrm{NO}$ conversion, the range of acceptable air-fuel ratio variability in gaseous engines should be lower than for gasoline engine. For this reason, the gaseous engine will be more liable to increase NO emissions during dynamic driving and rapid changes of vehicle speed and more liable to greater $\mathrm{NH}_{3}$ emissions. The cases presented in Figure 10 prove that in the engine fueled with propane, high $\mathrm{NH}_{3}$ emissions occurred only in the case of a simultaneous increase of $\mathrm{CO}$ and $\mathrm{NO}$ emissions (the invisible increase of $\mathrm{NO}$ emissions in Figure 10 was almost completely converted to $\mathrm{NH}_{3}$ ).

\section{Conclusions}

Widespread use of TWC in exhaust after-treatment systems of spark-ignition engines used in light-duty vehicles can result in ammonia formation in the exhaust gas. So far, this pollutant is not limited by international regulation regarding the light-duty vehicle, although emitted $\mathrm{NH}_{3}$ may increase the content of this component in the ambient air. Currently, a regulation exists of ammonia slip from ships and heavy-duty vehicles, and it is necessary to propose a method to eliminate this problem in other vehicles. Now is the right time to take this issue into account in the future Euro 7 regulation that is being developed.

Author Contributions: Conceptualization, A.Ż. and W.G.; methodology, A.Ż. and W.G.; software, A.Ż.; validation, A.Ż. and W.G.; investigation, A.Ż.; resources, A.Ż. and W.G.; data curation, A.Ż.; writing-original draft preparation, A.Ż.; writing—review and editing, A.Ż. and W.G.; supervision, A.Ż.; funding acquisition, A.Ż. and W.G. All authors have read and agreed to the published version of the manuscript.

Funding: This research received no external funding.

Institutional Review Board Statement: Not applicable.

Informed Consent Statement: Not applicable.

Conflicts of Interest: The authors declare no conflict of interest.

\section{References}

1. Public Health Statement: Ammonia. UN Agency for Toxic Substances and Disease Registry. Available online: https://www.atsdr. cdc.gov/ToxProfiles/tp126-c1-b.pdf (accessed on 27 January 2021).

2. Osha, U. Globally Harmonized System of Classification and Lablling of CHEMICALS (GHS); United Nation: Geneva, Switzerland, 2011. Available online: https:/ / www.unece.org/fileadmin/DAM/trans/danger/publi/ghs/ghs_rev04/English/ST-SG-AC1 0-30-Rev4e.pdf (accessed on 27 January 2021).

3. Pradhan, S. Development of an Ammonia Reduction After-Treatment Systems Development of an Ammonia Reduction AfterTreatment Systems for Stoichiometric Natural Gas Engines for Stoichiometric Natural Gas Engines. SAE Int. J. Engines 2017, 10, 104-109. [CrossRef]

4. Regulation (EC) No. 595/2009 of the European Parliament and of the Council of 18 June 2009. Off. J. Eur. Union L188 2009. [CrossRef]

5. Nevalainen, P.; Kinnunen, N.M.; Kirveslahti, A.; Kallinen, K.; Maunula, T.; Keenan, M.; Suvanto, M. Formation of NH3 and N2O in a modern natural gas three-way catalyst designed for heavy-duty vehicles: The effects of simulated exhaust gas composition and ageing. Appl. Catal. A Gen. 2018, 552, 30-37. [CrossRef]

6. Mejía-Centenoa, I.; Castillo, B.; Fuentesa, G. Enhanced emissions of NH3, N2O and H2 from a Pd-only TWC and supported Pd model catalysts: Light-off and sulfur level studies. Appl. Catal. B Environ. 2012, 119, 234-240. [CrossRef]

7. Suarez-Bertoa, R.; Zardini, A.A.; Astorga, C. Ammonia exhaust emissions from spark ignition vehicles over the New European Driving Cycle. Atmos. Environ. 2014, 97, 43-53. [CrossRef]

8. Adams, E.C. Catalytic Formation of Ammonia from Nitric Oxide. Ph.D. Thesis, Department of Chemistry and Chemical Engineering, Chalmers University of Technology, Gothenburg, Sweden, 2016.

9. Gong, J.; Rutland, C.H. Three Way Catalyst Modeling with Ammonia and Nitrous Oxide Kinetics for a Lean Burn Spark Ignition Direct Injection (SIDI) Gasoline Engine; SAE International: Warrendale, PA, USA, 2013.

10. Prikhodko, V.Y.; Pihl, J.A.; Toops, T.J.; Parks, J.E., II. Ammonia Generation over TWC with NOX Storage Component for Passive SCR NO $\mathrm{NO}_{X}$ Control in Lean Gasoline Engines. SAE Int. J. Engines 2014, 7, 1235-1243. [CrossRef]

11. Li, M.; Tian, H.; Wei, Z.; Zhang, Q.; Shen, B. Ammonia and nitrous oxide emissions of a stoichiometric natural gas engine operating with high caloric value and low caloric value fuels. Fuel 2021, 285, 119166. [CrossRef] 
12. Borsari, V.; de Vicente Assunção, J. Ammonia emissions from a light-duty vehicle. Clim. Chang. 2012, 111, 519-531. [CrossRef]

13. Sun, K.; Tao, L.; Miller, D.J.; Pan, D.; Golston, L.M.; Zondlo, M.A.; Griffin, R.J.; Wallace, H.W.; Leong, Y.J.; Yang, M.M.; et al. Vehicle Emissions as an Important Urban Ammonia Source in the United States and China. Environ. Sci. Technol. 2017, 51, 2472-2481. [CrossRef] [PubMed]

14. Gao, F.; Tang, X.; Yi, H.; Zhao, S.; Li, C.; Li, J.; Shi, Y.; Meng, X. A Review on Selective Catalytic Reduction of NOx by NH3 over Mn-Based Catalysts at Low Temperatures: Catalysts, Mechanisms, Kinetics and DFT Calculations. Catalysts 2017, 7, 199. [CrossRef]

15. Toops, T.J.; Parks, J.E., II; Pihl, J.A.; DiGiulio, C.D.; Amirdis, M.D. Lean Gasoline Emissions Control: NH3 generation over commercial Three-Way Catalysts and Lean-NOx Traps, Amiridis. In Proceedings of the 2012 DEER Conference, Dearborn, MI, USA, 18 October 2012.

16. Ribeiro, T.C. Understanding NH3 Emissions Over a Three-Way Catalyst in Lean/Rich Conditions; Instituto Superior Tecnico Lisboa Portugal: Lisboa, Portugal, 2015.

17. Prikhodko, V.Y. Passive Ammonia-SCR Catalyst System for $\mathrm{NO}_{X}$ Abatement from Lean-Burn Gasoline Engines: NH3 formation over TWC. Ph.D. Thesis, University of Tennessee, Knoxville, TN, USA, 2018.

18. Durbin, T.D.; Wilson, R.D.; Norbeck, J.M.; Miller, J.W.; Huai, T.; Bourns, S.R. Emissions of Ammonia from Light-Duty Vehicles. In Proceedings of the 10th International Emission Inventory Conference-“'One Atmosphere, One Inventory, Many Challenges”, Denver, CO, USA, 1-3 May 2001.

19. Durbin, T.D.; Wilson, R.D.; Norbeck, J.M.; Miller, J.W.; Huai, T.; Rhee, S.H. Estimates of the emission rates of ammonia from light-duty vehicles using standard chassis dynamometer test cycles. Atmos. Environ. 2002, 36, 1475-1482. [CrossRef]

20. Cant, N.W.; Chambers, D.C.; Liu, I.O.Y. The formation of isocyanic acid and ammonia during the reduction of NO over supported platinum group metals. Catal. Today 2004, 93, 761-768. [CrossRef]

21. Ma, H.; Schneider, W.F. DFT and microkinetic comparison of Pt, Pd and Rh-catalyzed ammonia oxidation. J. Catal. 2020, 383, 322-330.

22. Kean, A.J.; Littlejohn, D.; Ban-Weiss, G.A.; Harley, R.A.; Kirchstetter, T.W.; Lundenb, M.M. Trends in on-road vehicle emissions of ammonia. Atmos. Environ. 2009, 43, 1565-1570. [CrossRef]

23. Backes, A.M.; Aulinger, A.; Bieser, J.; Volker, M.; Quante, M. Ammonia emissions in Europe, part II: How ammonia emission abatement strategies affect secondary aerosols. Atmos. Environ. 2016, 126, 153-161.

24. Ntziachristos, L.; Samaras, Z. EMEP/EEA Air Pollutant Emission Inventory Guidebook 2019; European Environment Agency: Copenhagen, Denmark, 2019; pp. 79-84.

25. Michal Vojtíšek-Loma, M.; Beránek, V.; Klír, V.; Jindra, P.; Pechout, M.; Voříšek, T. On-road and laboratory emissions of NO, $\mathrm{NO}_{2}, \mathrm{NH}_{3}, \mathrm{~N}_{2} \mathrm{O}$ and $\mathrm{CH}_{4}$ from late-model EU light utility vehicles: Comparison of diesel and CNG. Sci. Total Environ. 2018, 616, 774-784. [CrossRef] [PubMed]

26. Lang, J.; Zhou, Y.; Cheng Sh Zhang, Y.; Dong, M.; Li Sh Wang, G.; Zhang, Y. Unregulated pollutant emissions from on-road vehicles in China, 1999-2014. Sci. Total Environ. 2016, 573, 974-984. [PubMed] 